sunlight ever penetrated the gloom; the research laboratories consisted of odd bits of passageway and the top of a proscenium arch, cut off for the acoustic conveniences of the hall below. Printing presses in the adjoining buildings clanged the harder as week-end editions became due, dust seeped in through every crevice and no plant had the least chance of survival, unless it was a fungus safely enclosed with all its requirements in a Petri dish.

Despite the handicaps, the students who arrived from all over the Greater London area, and indeed from beyond the seas, developed enthusiasm for their work and a great affection for the Department. They carried out publishable work on a variety of topics but predominantly on either cytology or the fungi. Many of them could only hope to attain academic distinction by way of evening classes because they were fully employed all day or were unable to pay the higher fees which would have been involved elsewhere. The full-time staff working under Dame Helen was small; but it was augmented in the evenings by botanists distinguished in their own fields, who came and gave specialist courses. To us all, teachers and taught, Dame Helen was a continual source of stimulus and inspiration. She never spared herself physically and carried out her distinguished researches on the fungi, while taking the very keenest interest in her staff and students, both past and present.

Those who best knew the old building will be the first to wish that the new Laboratory, with all its facilities, may create for itself an even greater tradition, built on the solid foundation of its inheritance and under the guidance of Prof. T. Ingold, the present holder of the chair.

LILY NEWTON

\section{INDIAN OILS AND FATS AND THEIR UTILIZATION}

A SYMPOSIUM on "Indian Oils and Fats and their Utilization" was held at the National Chemical Laboratory of India, Poona, during November 7-9, 1951. Prof. J. W. McBain, director of the Laboratory and chairman of the Vegetable Oils Committee, presided.

The scope of the symposium was explained by its organizer, Dr. J. S. Aggarwal, in charge of the Oils and Fats Section of the Laboratory. He said that India is the biggest oil-seed producing country in the world, and she contributes about 20 per cent of the world's production of oil seeds. Kamla oil, which in certain respects is better than non-available tung oil, is a great potential material resource of India. Pisa fat, which is almost pure trilaurin, is perhaps avail. able only in India, but is likewise completely neglected commercially. India's large production of many oil seeds has led to industries such as seed crushing, soap and glycerine, paints and varnishes and vanaspati. Although India is almost self-sufficient as regards these commodities, there is a great shortage of oils and fats. Other industries such as vegetable oil lubricants, greases, stearic and other fatty acids and other derivatives should also be developed. Dr. Aggarwal then suggested various methods for removing the shortage of edible oils, by increasing the overall output of oil seeds, adoption of solvent extraction, increased production of fish oils, and development of a flourishing dairy industry.
Dr. S. A. Saletore, assistant director, Centra] Laboratory for Scientific and Industrial Research, Hyderabad, then gave a brief report of the Oils and Fats Symposium that was held at Hyderabad during August 12-18, 1950. Altogether, seven papers on different subjects connected with oils and fats were read and discussed at that time.

At the present symposium, forty-eight papers were read and discussed under the following seven sections: (1) oil seeds and vegetable oils ; (2) oil extraction; (3) soap and glycerine; (4) hydrogenation of oils ; (5) fish oils ; (6) castor oil, drying oils, paints and varnishes; (7) analytical and other miscellaneous papers.

\section{(i) Oil Seeds and Vegetable Oils}

Mr. I. M. Qureshi, sylviculturist, Bombay State, Poona, in his paper on "Forest Oil Seed Wealth of Bombay State", discussed the methods of increasing the yields of forest oil seeds. A survey of such forest oil-bearing plants as kamla, pisa, butter trees and others is essential. Mr. R. C. Shrivastava, agricultural chemist, Madhya Pradesha, Nagpur, spoke on "Gokhru as a Source of Vegetable Oil". One acre of land can give $500-600 \mathrm{lb}$. of gokhru seeds containing 30-33 per cent semi-drying oils. The seeds can be removed from the thorny cover by shaking in 1.5-2 per cent sulphuric acid. The cake has a high content of phosphorus and nitrogen.

Mr. S. C. Gupta (National Chemical Laboratory) gave information about the availability of kamla seeds from the forests of the Punjab, U.P., Bihar, Bengal and Bombay States. The various characteristics of the seed oil and the constitution of kamlolenic acid, the new hydroxy fatty acid constituent isolated from the oil, were discussed. Utilization of kamla oil in air-drying wrinkle finishes and for other coating materials and the prospective uses of the hydrogenated kamlolenic acids were described. The cake is a rich source of nitrogen.

In a paper entitled "Utilization of Nim Oil", Mr. C. R. Mitra (National Chemical Laboratory) discussed the various aspects of industrial utilization of the oil on the basis of the researches carried out under the Council for Scientific and Industrial Research. The process of cold alcohol extraction of the oil ensures separation of the bitter constituents and their eventual utilization in pharmaceutical industry, and at the same time leaves the oil to be utilized for production of oleic and stearic acids. The extracted oil, when refined, is as good as any other vegetable oil and can be hydrogenated, when it may be put to various industrial uses, for example, high-grade soaps or high-melting sterin.

Dr. J. G. Kane, Department of Chemical Technology, University of Bombay, pointed out the drawbacks of mowrah oil for edible purposes. These are high acidity, deep coloùr, unpleasant smell and high unsaponifiable matter. Alcoholic refining was found to be good. By hydrogenation, products similar to mutton tallow and coco-butter could be obtained.

Mr. T. V. Rao directed attention to the catastrophic increase in the prices of oils and fats compared to those of the United Kingdom, especially that of coconut oil. Difficulties in the way of soap and vanaspati industries were discussed and some remedial measures suggested.

Mr. P. K. Patnaik, special officer, Oil Co-operative, Government of Orissa, read an interesting paper on 
"Oil and Allied Industries in the Future Development of India". In it he pointed out that though India leads the world in the production of oil seeds, the per capita consumption of fats and soaps is the least. In view of the many applications of oils and their products for nutrition, sanitation, protection against corrosion, medicine, lubrication, etc., this industry should receive special priority in the country's industrialization programme.

Shri Devendra Kumar Gupta, representative of the Akhil Bharat Sarva Seva Sangh, Wardha (M.P.), in his paper on the "Rational Utilization of the Oil Seed Wealth of the Country", pointed out that oils and fats are primarily meant for edible purposes. The seeds deteriorate and loss occurs during transport from villages to the big oil mills in the cities. The oil should, therefore, be extracted only in the villages in ghannies. He also demonstrated a model of the improved Wardha ghannie.

Mr. Om Prakash, oil expert to the Utter-Pradesh Government, brought to the notice of the audience that the Utter-Pradesh is the biggest mustardseed producing State in India and it exports a large amount of this oil to other States of the country; but on account of different specifications adopted by the various States, it is difficult for the trade to sell the oil. He stressed the necessity for uniform specification of this and other oils throughout India.

Shri Tulsidas M. Vishram, hon. secretary, Oil Merchants Chamber, Bombay, in his paper on "Trading in Vegetable Oils in India and its Future", described the great wastage of oils in transit due to leakage of the containers. He pressed for the production of a better and cheaper type of container. The other difficulty has been the different weights and measures in different parts of the country.

Mr. Krishan Gopal Mathur, chief chemist, Kusum Products, West Bengal, gave a very lucid description of the refining of vegetable oils as employed in India in industry.

\section{(2) Oil Extraction}

The paper of Mr. G. V. Datar, assistant engineer, Vill. Ind. Expt. Workshop, Poona, on "Nutan Ghannie", discussed various improvements in village ghannies, which resulted in Nutan ghannie now being available for introduction in Bombay State.

Dr. K. S. Murthi, principal, Oil Technological Institute, Anantapur, in his paper discussed the necessity of cotton-seed oil milling and refining in India. A paper on the "Prospects of the Oil Milling Industry in India" was also read and discussed by Shri Vallabhdas V. Mariwala, vice-president, Oil Merchants Chamber, Bombay.

The necessity, eccnomics and description of the solvent extraction process were very vividly and clearly discussed by Mr. H. V. Parekh, engineer, Bhavnagar Chemical Works, Ltd., Vartej (Saurashtra), Dr. N. G. Chatterji, manager, Hindustan Development Corporation, Ltd., Calcutta, and Mr. L. W. Richards, Bamag, Ltd., Bombay (read by Dr. R. J. Rathi, Poona).

In the absence of Mr. J. P. Verma (National Chemical Laboratory), his paper on "Extraction of Castor Oil through Aqueous Medium" was read by Dr. S. L. Shastry, who had carried out the large-scale experiments. With the aid of certain chemicals, castor oil in very good yield can be obtained from seed meal by heating with water. The characteristics of the oil are identical with those of ordinary castor oil.
Mr. T. K. Nayar, representative, Burmah Shell, reported the availability of petroleum solvents for oil extraction in India. A special solvent, Pegasol 1222, was also reported to be available from $\mathrm{M} / \mathrm{s}$ Standard Vacuum Oil Co., Bombay.

\section{(3) Soap and Glycerine}

Dr. Ing. B. P. Godrej, director, Godrej Soaps, Ltd., Bombay, in his paper on "Commercial and Economic Aspects of Indian Soap Industry", pointed out that though the major soap producers have well-equipped plants, the high prices of oils (especially coconut and mahua) reduce the profits to almost nothing. The production of caustic soda is still not sufficient in the country. The various other economic aspects were also discussed.

A very informative paper on the use of non-edible oils in soap-making in India was presented by Mr. G. Ford and Dr. G. S. Hattiangadi, of Lever Brothers (India), Itd., Bombay. Linseed, mowrah and castor oils, rosin, soap stock and acid oil are the chief nonedible raw materials used in India. However, these are not being produced commercially. The nonavailability of the seeds and their uneven quality, etc., are the chief difficulties.

Dr. N. N. Godbole, director of industries and commerce, Rajasthan, Jaipur, discussed sweating in soaps and remedies for preventing it. He stated that some cheap oils such as karanja, neem and others had been used in the production of soap; but after some time, the soap became discoloured and hence could not be sold. Naturally, these defects should be remedied. Mr. G. M. Kelkar, in charge of village industries, Research Laboratory, Poona, exhibited samples of soaps made from the above oils.

The paper on the "Refining of Glycerine by Ion Exchange Resins" by Dr. H. A. Shah (National Chemical Laboratory) stated that soap-lye or crude glycerine contains as impurities mostly sodium chloride and organic colouring matter. This can be purified by passing it through a column of cation and anion exchange resins. Glycerine of sufficient purity for most applications may thus be obtained by simply concentrating the treated lye.

\section{(4) Hydrogenation of Oils}

Dr. M. Damodaran, assistant director, National Chemical Laboratory, gave a very informative talk on the nutritional value of vanaspati, reporting that as a result of the work earried out at four research centres in India, it has definitely been established that vanaspati is as good in nutrition value as any other fat, if its melting point remains below the human body temperature.

Mr. A. E. Shohet, the Hindustan Vanaspati Manufacturing Co., Ltd., Bombay, gave a brief survey of the vanaspati industry in India. The development of the industry, capital invested, contribution of this industry to the State exchequer, consumption of butter and ghee and vanaspati in India and other countries, specifications for vanaspati, etc., were described.

In his paper on "A Study of Catalysts in Vanaspati Production", Mr. D. D. Nanavati, chief chemist, Palanpur Vegetable Products, Ltd., Gujrat, stated that the production of vanaspati with the physical characteristics of ghee depends upon the catalysts. The various methods of reduction of the nickel catalyst for use in the hydrogenation industry were very clearly described. 
Dr. R. K. Trivedi, industrial chemist, Itraco, Ltd., Bombay, described by means of a diagram the highpressure technique employed in fat splitting in the industry and its advantages over other known methods. A description of the prccess for hydrogenation of the fatty acids to give higher aliphatic alcohols was also given.

\section{(5) Fish Oils}

The one paper in this section was from Mr. S. M. Arsiwala, Department of Fisheries, Bombay, on "Shark Liver Oil Industry in India". Vitamin contents of various fish oils, method of extraction of the oil, concentration of vitamin A, the capsulating process, and importance of vitamins were all indicated. Besides its medicinal value, low-grade oil is used in industry in leather tanning, manufacture of paints, varnishes, printing inks, oil cloth and linoleum. Livers of sharks are also found to be very rich in anti-anæmic factors.

(6) Castor Oil, Drying Oils, Paints and Varnishes

Dr. K. T. Achaya, Central Laboratories for Scientific and Industrial Research, Hyderabad, read a paper on "Some Investigations on Hydroxy Oils, particularly Castor", in which he suggested that the refractive index should be made the basis of evaluation of hydroxy oils and acids. Methods for the concentration of tri-ricinolein, preparation of pure ricinoleic acid and sodium ricinoleate from castor oil were briefly described. A method for analysis of hydroxy fatty oils using ester fractionation was illustrated.

Prof. K. K. Dole, professor of chemistry, Fergusson College, Poona, reported that some sulphonic acids and their salts have been found to be effective catalysts for the dehydration of eastor oil. A process of rapid continuous dehydration of the oil by the use of certain catalysts was also demonstrated. Mr. M. A. Sivasamban, Central Laboratories for Scientific and Industrial Research, Hyderabad, gave a brief report of his work on the use of local clays for dehydration of castor oil. The presence of a small amount of sodium bisulphate used with the clays was found to be more effective. Conditions were also worked out for dehydration on a pilot-plant scale.

Mr. R. K. Banerji, Murarka Paints and Varnish Works, Ltd., Calcutta, and a representative of the Paint Manufacturers Association, gave a brief description of his work on synthetic drying oils obtained by the condensation of the fractions of petroleum oils and higher aliphatic alcohols.

Dr. S. A. Saletore, in his paper on "Drier Effects on Drying of Oil Films", reviewed the earlier work on dryer action. Three phases in the absorption of oxygen by linseed oil at $96^{\circ} \mathrm{C}$. in presence of lead and cobalt dryers were discussed. The effects of a number of organic compounds in the drying of oils were also included.

Mr. P. G. Sharma gave a brief review of the extensive work carried out in the National Chemical Laboratory on the utilization of tobacco seed oil in surface coatings, as in paints and varnishes, after isomerization, air-drying wrinkle finishes, preparation of alkyd resins, and its metallic salts after polymerization. Other possible uses of the oil, such as the formation of factice, illuminant and for edible purposes, were also discussed.

Mr. H. H. Mathur described the work done in the National Chemical Laboratory on the employment of cashew shell liquid for surface coatings.
Dr. D. J. Mehta (National Chemical Laboratory) then reported briefly on his research work on the employment of vegetable oils for the preparation of alkyd resins from tetrachlorophthalic anhydride. These materials can be used in fire-retardent paints. Mr. Om Prakash also gave a brief summary of the work carried out at the H.B. Technological Institute, Kanpur, on the use of vegetable oils such as linseed and castor oils for modified alkyd resins.

\section{(7) Analytical and Other Miscellaneous Papers}

Dr. N. N. Godbole, in his talk on the analysis of butter fat, stressed the importance of the butyric acid number. He said that the $A$ and $B$ values of the butter fat are more accurate than other values such as Reichert-Meissel and Polenske values of such fats. 'The acetyl value of the butter fat is also found to increase with time. Dr. S. S. Gupta (National Chemical Laboratory) gave a brief survey of recent advances in the analysis of oils and fats, such as the preparation of fatty acids and glycerides by low-temperature crystallization technique and utilization of ultra-violet spectra in the analysis of various unsaturated fatty-acid mixtures. The description of the former process and its utilization in the industry in other countries was a subject of another paper by Dr. C. B. Patel, Industrial Research Laboratory, Department of Industries, Bombay. Limitations of the low-temperature erystallization technique were also discussed. In the absence of the author, the paper was read by Mr. H. H. Mathur (National Chemical Laboratory).

Dr. A. R. S. Kartha, Maharaja's College, Eranakulam, then gave a brief report of his work on "Recent Advances in the Study of Glyceride Composition of Natural Fats", which led ultimately to the development of acetic acid-acetone permanganate oxidation of fats and separation by magnesium salts of the azelo-glycerides. Another paper by the same author was on "Some Regularities in the Melting and Solidifying Points of Mixtures of $\mathrm{GS}_{3}$ with non-GS $\mathrm{G}_{3}$ Glycerides and of Saturated with Unsaturated Fatty Acids". A simple mathematical rule was found to hold good in these cases. The various implications of these rules were also discussed.

Mr. V. S. Govindarajan (National Chemical Laboratory) gave a brief review of the application of different chromatographic procedures in the analysis of fatty oils and fatty acids. The usefulness of the process in the separation of pure fatty acid from the mixture and for the isolation of hydrocarbons from triglycerides was also discussed.

Mr. S. C. Sethi then gave a short account of the work carried out at the National Chemical Laboratory on the stabilization of edible fats by spices and condiments.

Dr. J. W. Airen, professor of chemistry, Wilson College, Bombay, briefly described his work on the analysis of carilla oil and the formation of its gel on keeping. On further storage the gel is retransformed into a viscous liquid.

Dr. B. R. Y. Iyengar (National Chemical Laboratory), in his paper on the "Application of Electrical Testing Methods in the Processing of Oils", stated that a study of the electrical properties, such as the dielectric constant and the dielectric loss, can serve as a means of following and controlling the extent and the nature of the processing of oils. Reactions like oxidation, polymerization, etc., can be followed with a rapidity unattainable by the normal time. consuming chemical methods. 
The last paper on the programme was "Vegetable Oils as Petroleum Products Substitute", by Dr. M. L. Khanna, National Physical Laboratory, New Delhi. The paper was read by Mr. A. S. Gupta (National Chemical Laboratory). It described the work carried out by the Council for Scientific and Industrial Research on the utilization of vegetable oils as lubricants and diesel fuels. These oils can also be used for lubricating greases.

It was tentatively decided that the Symposium on Oils and Fats will be held next year at Bombay under the auspices of the Oil Merchants Chamber, though a warm invitation had also been received from the Oil Technologists Association, Kanpur.

$$
\text { J. S. Aggarwat }
$$

\section{NEW ZEALAND DEPARTMENT OF SCIENTIFIC AND INDUSTRIAL RESEARCH}

\section{ANNUAL REPORT FOR 1950-5I}

$\mathrm{T}$

HE twenty-fifth annual report* of the Depart. ment of Scientific and Industrial Research, New Zealand, covers the year ended March 31, 1951, and includes the Minister's statement, the Secretary's report and the reports from the branches, research committees, research associations, etc. The net expenditure for the year was $£ 903,550$, of which $£ 316,296$ was incurred in research investigations, $£ 184,318$ for the Dominion Physical Laboratory, $£ 127,740$ for the Dominion Laboratory, $£ 78,933$ for the Geological Survey, and $£ 57,355$ for the Information Bureau, Scientific Liaison Services and miscellaneous services. Grants to universities and agricultural colleges amounted to $£ 35,538$, and to research associations to $£ 25,959$. Of a total staff of 1,010 , there were 386 professional and 450 technical officers.

During the year the Department's activities in geophysics were grouped under a Geophysics Division, and a major activity of the year was the search for suitable geological structures in the Wairakei thermal region which will enable the geothermal steam and hot-water resources of the area to be utilized for power and industrial purposes. Although good progress has been made in the exploratory work, much further research will be required before utilization is possible. In association with the Geological Survey and the Geophysics Division, Dr. E. Lehner, consultant to the Anglo-Iranian Oil Co., examined all likely petroliferous regions, and his report on their potentialities as sources of petroleum is under consideration. The Secretary's report also emphasizes the economic value of some of the research findings of the Department. Thus the persistent efforts of the Botany, Soil, Plant Diseases and Entomology Divisions have now defined the dreaded yellow-leaf disease of phormium as a virus disease transmitted by the insect Oliarus atkinsonii, thus clarifying the attack on the problem by plant breeding and management practices. Studies of the New Zealand grass-grub, which causes very serious losses annually, have shown how this pest can be controlled economically with DDT and 'Gammexane'. Research on varieties, diseases and fertilizer treatment of the tobacco crop have contributed

* New Zealand. Twenty-fifth Annual Report of the Department of Scientiflc and Industrial Research. Pp. 80. (Wellington: Government Printer, 1951.) 18. 6d. to an increase in average yield of dried leaf per acre from $659 \mathrm{lb}$. to $1,155 \mathrm{lb}$. in four years, or $£ 748 s$. per acre at the current basic average price of leaf.

The researches of the Fats Research Laboratory and the Dominion Physical Laboratory have contributed to the establishment of a fish liver-oil industry worth $£ 200,000$ annually and utilizing material previously neglected. Pasture research at the Grasslands Division has yielded strains of grasses and clovers and a system of management enabling the production of 12-16 thousand lb. dry matter per acre annually. Since a figure of $4,000 \mathrm{lb}$. is required to yield $200 \mathrm{lb}$. of butter-fat per acre, the potential value of this increase to the New Zealand butter industry is obvious. The value of short-rotation ryegrass seed developed by this Division is estimated at $£ 150,000$ annually over the last three year, apart from the grazing value of the ryegrass. Disease control investigations by the Plant Diseases Division are estimated to have effected annual savings of $£ 250,000$ to the grazier through reduced losses in dry rot of swedes; control of mealybug of glasshouse grapes with DDT has yielded annual savings of $£ 18,000$ and of eelworm and verticillium wilt of tomatoes in

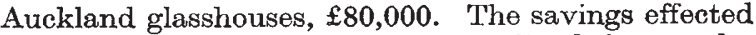
in interior renovations of plaster-lined houses by control of black-mould are estimated at $£ 42,000$ annually.

From the reports from branches, only a few points can be selected for mention. Meat research on production of dehydrated meat in large-sized pieces with a more acceptable texture than mince has yielded a product with a well-distributed moisture content, of acceptable appearance and palatable when cooked, and a pilot plant is projected. The study of resinous constituents of exotic pines was continued in co-operation with the New Zealand Forest Service. The programme of simultaneous measurements of absorption of radio waves reflected by the ionosphere obliquely (in passage between Awarua and Lower Hutt) and vertically (at Christchurch) was completed. In the Fats Research Laboratory it has been estab. lished that the more highly unsaturated acids are important in connexion with the onset of rancidity in butter-fat, and in the $\mathrm{C}_{18}$ series the triene acid present is linolenic acid, the main fatty constituent of pasture. Branched-chain fatty acids also occur in butter-fat. From April 1, 1951, the Geophysical Observatory, Wellington, has been renamed the Oceanographic Observatory, and studies of marine conditions in New Zealand waters have commenced. The Plant Chemistry Laboratory has continued its work on the synthesis of leaf protein from nitrate and ammonia derived from the soil with a further microbiological and chromatographic study of the aminoacids in leaf sap. The Seismological Observatory reports that seismic activity during 1950 was most intense during the first three months, the severest earthquake of the year occurring on March 1, 1951, in the region between Taupo and Waikaremoana. The Wheat Research Institute studied the sugar needs of fermenting doughs and found that these are much higher for long dough processes than for short ones. The Cawthron Institute completed its survey of hop soils, continued its studies of the role of traceelements in Nelson crops, and again surveyed hopgardens for the presence of black root-rot.

The Pottery and Ceramics Research Association was expanded to include the heavy clay products industry. Trials at the Dairy Research Institute showed that addition of 0.005 per cent of the anti- 